\title{
Degradation of low-rank coal excavated from coal-mine Záhorie by filamentous fungi
}

\author{
Eva Smoleňová ${ }^{1}$, Richard Pokorný ${ }^{1}$, Michal Kaliňák ${ }^{2}$, \\ Tibor Liptaj ${ }^{2}$, Martin Šimkovič ${ }^{1}$, Ludovít Varečka ${ }^{1}$ \\ ${ }^{1}$ Institute of Biochemistry and Microbiology \\ ${ }^{2}$ Central Laboratories, Slovak University of Technology, Radlinského 9, 81237 Bratislava, Slovakia \\ ludovit.varecka@stuba.sk
}

\begin{abstract}
The ability of Trichoderma strains isolated from lignite and of Earth surface-derived strains to attack (solubilise) lignite, peat and wood was compared using glutamate as a carbon source. The results showed that lignite-derived microorganisms solubilise lignite to similar extent as Trichoderma strains isolated from the Earth surface. Solubilisation processes involve the action of enzymes and alkaline $\mathrm{pH}$. The solubilisation of lignite was accompanied by a small increase of conidia-bound laccase, whereas that of peat was accompanied by (secretion) activity of cellulase, laminarinase, laccase, and lignin-peroxidase-like enzyme. In addition, data were obtained which show that bacteria contained in the lignite are able of lignite solubilisation and utilisation.
\end{abstract}

Key words: Trichoderma species, low-rank coal, solubilisation

\section{Introduction}

Since the beginning of the 1980 's it is known that some micro-organisms are able to attack hard- and low-rank coals (lignite) (Fakoussa, 1981; Cohen et al., 1987; Hölker et al., 1995; Fakoussa and Hofrichter, 1999). Several species of bacteria, basidiomycetes, deuteromycetes, zygomycetes and ascomycetes able to solubilise/depolymerise this heterogenous complex organic material have been described since (Klein et al., 2001). Microorganisms use different mechanisms for an attack on the coal structure. Known strategies of ascomycetes, deuteromycetes and bacteria to solubilise lignite are the extrusion of alkaline substances, secretion of chelators, production of detergents and the action of hydrolases (Hölker et al., 1999, 2002b). Basidiomycetes use also ligninolytic enzymes e.g. lignin-peroxidase, manganese-peroxidase and laccase (Fritsche et al., 1999). More than 750 fungal species were screened to find fungi which are able to modify coal (Hofrichter et al., 1999). Microorganisms were isolated from open cast mining areas, forest fire regions, decaying wood or abandoned mines under conditions in which the probes could have been contaminated by surface microorganisms that have only incidental biological contact with coal. All known isolates from lignite were obtained from the surface and they were exposed to the environment for an undefined time. Results of solubilisation experiments were reviewed by Sekhohola et al. (2013).

Recently, several papers confirmed the capability of fungi to solubilise various types of coal (Yuan et al., 2006, Kliăn et al. 2013) or to remove not desired constituents of coal (Etemadzadeh et al., 2016). Supporting effects of bacteria (Liu et al., 2019) or plants (Mukasa-Mugerwa et al., 2011) in the fungal attacks of coal have been observed.

The aim of this study was to determine whether fungi of genus Trichoderma residing within lignite have higher lignite-solubilisation potential than their counter-parts collected from the Earth surface. Fungal species were isolated from the underground of a lignite mine (Záhorie, Slovakia) from the depth of about $170 \mathrm{~m}$ (Pokorný et al., 2005). Several Trichoderma $s p$. were isolated under sterile conditions from lignite and identified by sequencing of their internal transcribed spacers (ITS). Lignitedepolymerisation activity of these "indigenous" fungi was compared with that of Trichoderma strain isolated from the Earth surface. Solubilisation of peat and wood were also investigated.

\section{Materials and Methods}

\section{Strains}

Strains used in this work were isolated from the underground of lignite mine Záhorie, Slovakia, except for Trichoderma sp. var. Modra, which was isolated from the rotten wood bark found near the town Modra, Slovakia. The isolate Trichoderma sp. var. Čary, was isolated from the lignite layer in the drift wall opened to air for several years after cutting off the surface layer by a sterile chisel. The same is true for Trichoderma, var. Store which was isolated from a compact piece of coal found at the store of freshly excavated coal. Its ITS1 sequence showed a $98 \%$ similarity to T. atroviride. Trichoderma isolates, designated as Čelba 1 and Čelba 2 also characterised by their ITS sequences.

The obtained sequences were submitted to GenBank and are available under the accession num- 
bers AY220263-AY220269. Their analyses showed that the isolated species from coal are closely related to Trichoderma viride and/or Trichoderma atroviride whereas Trichoderma sp. var. Modra is related to Trichoderma pseudokoningii.

Fungal isolates were propagated on Czapek-Dox agar supplemented with $0.5 \%(\mathrm{w} / \mathrm{v})$ yeast extract at $26{ }^{\circ} \mathrm{C}$ in dark. For experiments, conidia were scrapped from the agar surface and washed once with water and counted. Isolated bacteria were cultivated on Nutrient Broth (HiMedia) plates at $37^{\circ} \mathrm{C}$.

\section{Isolation of microbial strains from lignite}

The isolation procedure was extensively described in our previous paper (Pokorný et al., 2005). Using this procedure, both fungi and bacteria were isolated.

\section{DNA isolation from fungi}

DNA was isolated from the liquid nitrogen-frozen vegetative mycelia by phenol-chloroform extraction according to the standard procedure (Ausubel et al., 1992) with some modifications described elsewhere (Scheel et al., 1997, 1999, 2000).

\section{Molecular typing of Trichoderma isolates}

For the amplification of ITS fragments, primers ITS1 and ITS4 were used (White et al., 1990) resulting in bands at about $600 \mathrm{bp}$. For the amplification of mitochondrial small subunit rRNA gene fragments, primers MS1 and MS2 (White et al., 1990) were used giving bands at about $650 \mathrm{bp}$. The bands were purified by QIAquickGel Extraction Kit (QIAGEN) and PCR sequenced using an ABI Prism sequencer. The sequences were analysed by the ClustalX program using available Trichoderma ITS and mitochondrial small subunit rRNA gene sequences.

\section{Lignite, peat, and wood solubilisation}

Lignite solubilisation was performed and monitored as described elsewhere (Hölker et al., 1995) with lignite sterilisation by autoclaving in some experiments. In experiments with $\mathrm{H}_{2} \mathrm{O}_{2}$-preoxidation/ sterilisation, ampicillin $\left(100 \mu \mathrm{g} \cdot \mathrm{ml}^{-1}\right)$ was added to prevent the growth of bacteria. Peat (finely chopped peat was purchased at the local garden centre and used without treatment) solubilisation was measured in the same way but sterilisation was done by autoclaving only. Wood (beech) sawdust (fine powder was obtained from a carpenter workshop and used without treatment) was also sterilised by autoclaving and solubilisation was monitored by measuring $\mathrm{A}_{280}$ in the aliquots of cultivation media centrifuged, the cultivation broth was deproteinised with $10 \%$ perchloric acid before the measurement. For inocu- lation, $100 \mathrm{ml}$ of media inoculated with $1 \times 10^{6} \mathrm{co}-$ nidia/ $\mathrm{ml}$ were used. Solubilisation was carried out at $25^{\circ} \mathrm{C}$ for the time indicated in the figures with $1-3 \mathrm{~g}$ of particulate material in $100 \mathrm{ml}$ of medium.

\section{Enzyme assays}

Lignin peroxidase-assay: activity was determined spectrophotometrically by oxidation of veratryl alcohol. The reaction mixture (total volume of $3 \mathrm{ml}$ ) contained $1 \mathrm{ml}$ of the sample, $1.95 \mathrm{ml}$ of $150 \mathrm{mmol} \cdot \mathrm{l}^{-1}$ Na-tartrate buffer, $\mathrm{pH} 3$, and $0.67 \mathrm{mmol} \cdot \mathrm{l}^{-1}$ veratryl alcohol. The reaction was started by the addition of $\mathrm{H}_{2} \mathrm{O}_{2}\left(0.12 \mathrm{mmol} \cdot \mathrm{l}^{-1}\right)$ and the change of $\mathrm{A}_{310}$ was measured for $1 \mathrm{~min}$ at $25^{\circ} \mathrm{C}$. Molar absorption coefficient, $\varepsilon=9300 \mathrm{l} \cdot \mathrm{mol}^{-1} \cdot \mathrm{cm}^{-1}$, was used for the calculation of enzyme activity.

Mn-peroxidase-assay: the activity was assayed spectrophotometrically by $\mathrm{Mn}^{3+}$-induced oxidation of phenol red (Kuwahara et al., 1984). The reaction mixture (total volume of $3 \mathrm{ml}$ ) contained $1 \mathrm{ml}$ of the sample, $1.95 \mathrm{ml}$ of $75 \mathrm{mmol} \cdot \mathrm{l}^{-1} \mathrm{Na}$-tartrate buffer, $\mathrm{pH} 4.5$, containing $0.15 \mathrm{mg} \cdot \mathrm{ml}^{-1}$ phenol red, and $0.1 \mathrm{mmol} \cdot \mathrm{l}^{-1} \mathrm{MnSO}_{4}$. The reaction was started by the addition of $\mathrm{H}_{2} \mathrm{O}_{2}\left(0.05 \mathrm{mmol} \cdot \mathrm{l}^{-1}\right.$ final $)$ and the change of $\mathrm{A}_{610}$ was measured for $5 \mathrm{~min}$ at $25^{\circ} \mathrm{C}$.

Laccase was measured using ABTS (2,2'-azinobis-(3-ethylbenzothiazoline-6-sulfonate)) as the substrate employing the following procedure: $3.5 \mathrm{ml}$ of solubilisation mixture were centrifuged $(5 \mathrm{~min}$ at $12000 \times \mathrm{g}$ ) and the resulting pellet was vortexed with $1.35 \mathrm{ml}$ of $100 \mathrm{mmol} \cdot \mathrm{l}^{-1}$ citratephosphate buffer, pH 5.4. ABTS $\left(0.3 \mathrm{mmol} \cdot \mathrm{l}^{-1}\right.$ final) was added, vortexed and incubated for $10 \mathrm{~min}$ at $37^{\circ} \mathrm{C}$. The reaction was terminated by centrifugation of the suspension for $2 \mathrm{~min}$ as above and $\mathrm{A}_{420}$ was measured. Reference sample $(t=0)$ was centrifuged immediately after substrate addition. The difference of $\mathrm{A}_{420}$ at 10 and $0 \mathrm{~min}$ and $\varepsilon=36000 \mathrm{l} \cdot \mathrm{mol}^{-1} \cdot \mathrm{cm}^{-1}$ was used to calculate enzyme activity.

Activities of amylase ( $\alpha$-1,4-glucanase), cellulase ( $\beta$-1,4-glucanase), dextranase ( $\beta$-1,6-glucanase), laminarinase ( $\beta$-1,3-endoglucanase), lichenase ( $\beta$-1,3-1,4-endoglucanase) and xylanase ( $\beta-1,4$ xylanase) were detected using chromolytic substrates according to the following procedure: $0.1 \mathrm{ml}$ aliquots of centrifuged solubilisates were diluted with $0.5 \mathrm{ml}$ of $100 \mathrm{mmol} \cdot \mathrm{l}^{-1}$ citrate-phosphate buffer, pH 5.4, one tablet of chromolytic substrate (corresponding polysaccharide covalently modified with blue dye) was added and the mixture was incubated for $24 \mathrm{~h}$ at $25^{\circ} \mathrm{C}$. The reaction was terminated by the addition of $3.5 \mathrm{ml}$ of the stopping solution $\left(5 \mathrm{~g}\right.$ of $\mathrm{Na}_{2} \mathrm{CO}_{3}$, $50 \mathrm{ml}$ of acetone and $450 \mathrm{ml}$ of water), the suspension was centrifuged, and $A_{620}$ of the supernatant was measured against water. 
Activities of cellulase, dextranase, and laminarinase were determined also by the spectrophotometrical measurement of the release of reducing substances using the 3,5-dinitrosalicylic acid (DNS) method. The assay was performed as follows: $0.1 \mathrm{ml}$ of the centrifuged solubilisate was added to $0.9 \mathrm{ml}$ of $1 \%$ suspension of the corresponding polysaccharide in $50 \mathrm{mmol} \cdot \mathrm{l}^{-1}$ citrate-phosphate buffer, $\mathrm{pH}$ 7, and incubated for $5 \mathrm{~min}$ at $40{ }^{\circ} \mathrm{C}$ (cellulase), for $40 \mathrm{~min}$ at $40^{\circ} \mathrm{C}$ (laminarinase), or up to $60 \mathrm{~min}$ at $40{ }^{\circ} \mathrm{C}$ (dextranase). In parallel, control samples were incubated for $0 \mathrm{~min}$. Aliquots of $0.15 \mathrm{ml}$ were withdrawn and added to $0.25 \mathrm{ml}$ of $1 \%(\mathrm{w} / \mathrm{v}) 3$, 5 -dinitrosalicylic acid in $0.4 \mathrm{~mol} \cdot \mathrm{l}^{-1} \mathrm{NaOH}$ containing $30 \%(\mathrm{w} / \mathrm{v})$ of $\mathrm{Na}$, K-tartrate. The solutions were boiled for $5 \mathrm{~min}$, diluted with $1 \mathrm{ml}$ of water, and centrifuged for $3 \mathrm{~min}$ at $12000 \times \mathrm{g}$. $\mathrm{A}_{540}$ was measured against reference with $0.15 \mathrm{ml}$ of water instead of the sample. All values were corrected for $A_{540}$ obtained from zero-time samples. The amounts of reducing compounds were read from the calibration line constructed with glucose as the standard compound.

\section{${ }^{1} \mathrm{H}$-NMR measurements}

${ }^{1} \mathrm{H}-\mathrm{NMR}$ spectra were obtained on a Varian VXR300 spectrometer operating at $299.943 \mathrm{MHz}$ for protons. Neutralised and lyophilised samples were dissolved in $\mathrm{D}_{2} \mathrm{O}$ in a 5 -mm NMR tube and measurements were performed at ambient temperature. Chemical shifts were referenced to the internal standard - TSP (0.00 ppm). Standard ${ }^{1} \mathrm{H}$ spectra were acquired and processed using standard acquisition and processing parameters. The signal of residual water was suppressed by selective pre-saturation ( $5 \mathrm{~s}$ ).

\section{Protein determination}

Proteins were determined by the Bradford method after the extraction of biomass with $0.1 \mathrm{~mol} \cdot \mathrm{l}^{-1}$ $\mathrm{NaOH}$ for $1 \mathrm{~h}$ at $70^{\circ} \mathrm{C}$ followed by 5 min centrifugation at $12000 \times \mathrm{g}$. Supernatant was used for protein determination.

\section{Chemicals}

ABTS, laminarine and L-glutamic acid were purchased from Sigma-Aldrich, St. Louis, MO, U.S.A.; veratryl alcohol was from Fluka, Buchs, Switzerland and T 150-dextran from Pharmacia, Uppsala, Sweden. Chromolytic substrates for the determination of amylase, cellulase, dextranase, laminarinase, lichenase and proteinase were synthesised and generously provided by Dr. Ludovít Kuniak, from the Department of Food Technology, Slovak University of Technology, Bratislava, Slovakia. Other chemicals were purchased from
Microchem, Pezinok, Slovakia, or from Lachema, Brno, Czech Republic.

\section{Results}

\section{Solubilisation experiments}

Solubilisation experiments were performed with Trichoderma sp. var. Čáry using $1.2 \%$ L-glutamate as the carbon source (substitution of glutamate by glutamine or $\alpha$-oxoglutaric acid did not significantly influence the solubilisation process). The amount of solubilisate was dependent on the mass of lignite added (Fig. 1). The presence of glutamate (or glutamine, or $\alpha$-oxoglutaric acid-not shown) led to the alkalinisation of the medium to $\mathrm{pH}$ of about 8 in the course of solubilisation. It should be noted that the capability of this fungus to solubilise lignite gradually decreased within one year to about $30 \%$ of the values obtained using fresh isolate without any changes in the measured enzyme activities or growth rate (not shown). The efficiency of solubilisation of two "indigenous" Trichoderma strains (Čelba 1 and Čelba 2) and of (not necessarily "indigenous") Trichoderma sp. var. Čáry (or Trichoderma sp., var. Store) strains did not differ dramatically from that of the strain used in previous experiments (Hölker et al., 1999), although individual isolates differed from each other (Fig. 1). Lignite dry mass decreased during the solubilisation process after 30 days of cultivation by approximately $10 \%$ for Čelba 1 and $20 \%$ for Čelba 2.

The next experiment was focused on the lignite solubilisation activity of the tested fungi being due to media alkalinisation or activation of specific enzymatic mechanism. Lignite solubilisation was performed with glutamate or sucrose as the carbon source in a heavily buffered medium $\left(100 \mathrm{mmol} \cdot \mathrm{l}^{-1}\right.$ Tris/HCl, pH 8). It was found that the buffered alkaline medium leads to stronger solubilisation than the non-buffered one. Moreover, the ability to solubilise lignite was no more restricted to the amino acids or carboxylic acids as carbon source and proceeded with the same intensity, even better, with sucrose as the carbon source (Fig. 2). As sucrose is a metabolically more efficient carbon source than glutamate, this experiment indicates that also other aspects of fungal metabolism beside media alkalinisation contribute to lignite solubilisation.

Solubilisation activity of Trichoderma was tested also with less mineralised substrates, i.e. peat and wood sawdust. It was found that Trichoderma sp. var. Čáry solubilises autoclave-sterilised peat with the solubilisate yield comparable to that from lignite (Fig. 3). The use of wood (beech) sawdust as particulate material led to the release of soluble compound(s) 

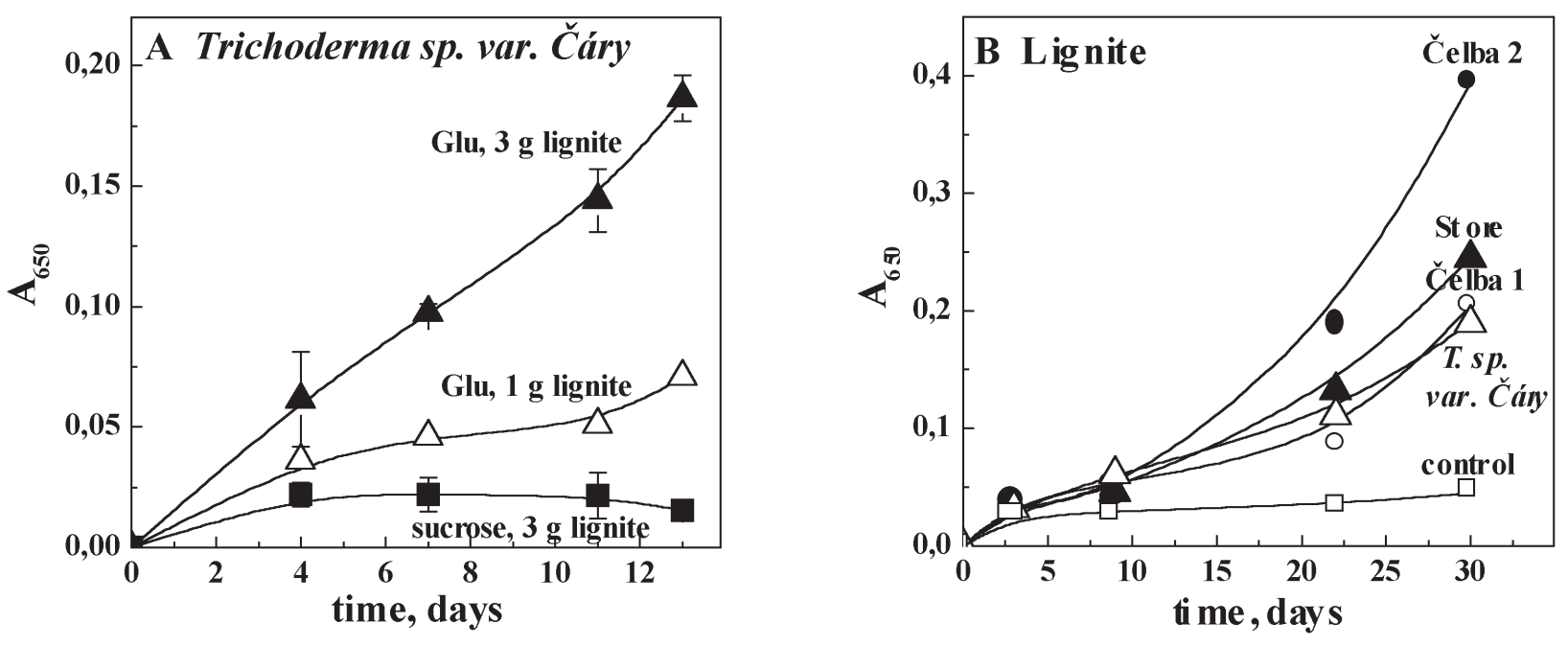

Fig. 1. Solubilisation of lignite by Trichoderma isolates.

A: Dependence of solubilisation on the mass of sterilised lignite using glutamate or sucrose as carbon sources. The process was carried out as described in Materials and Methods.

B: Comparison of lignite solubilisation activity of recent and fossile strains of Trichoderma. Trichoderma isolates: isolate Trichoderma sp. var. Čáry (open triangles) was isolated from the surface of the lignite layer in a drift wall (lignite mine Záhorie, Čáry, Slovakia) opened several years ago, isolate named as "Store" (closed triangles) was isolated from the surface lignite store in this mine and isolates named as "Čelba 1" (open circles) and "Čelba 2" (closed circles) were isolated from the underground place called "Čelba" where a tunnel-drilling machine is operated. Solubilisation was carried out with $1 \mathrm{~g}$ of sterilised lignite per assay and the procedure described in Materials and Methods was followed. Control (open squares) was represented by non-inoculated sterilised lignite. Glutamate $(2 \% \mathrm{w} / \mathrm{v})$ was used as carbon source.

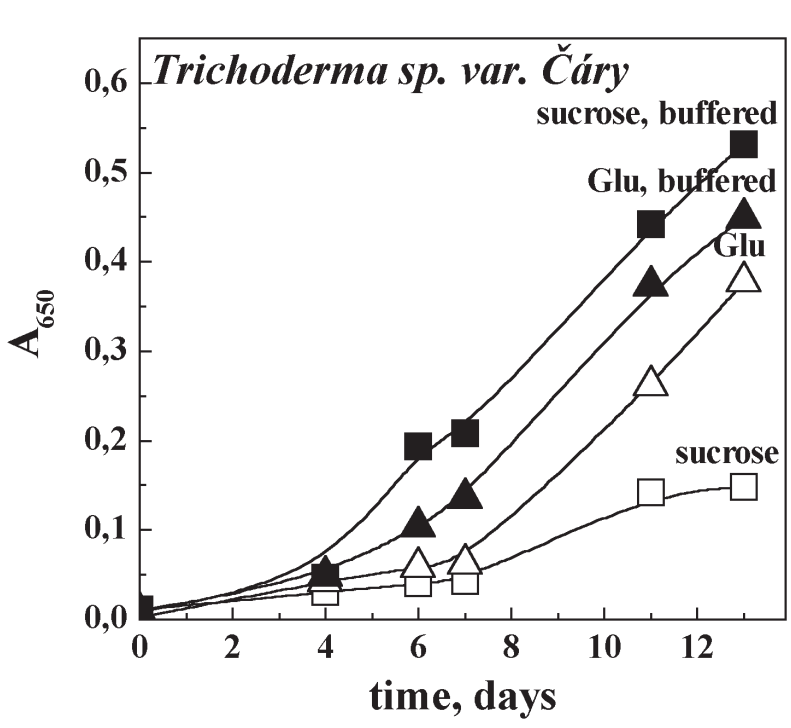

Fig. 2. Effect of buffering on solubilisation activity of Trichoderma sp. var. Čáry with sucrose and glutamate as carbon sources in non-buffered or buffered medium.

The experiment was performed as described in

Materials and Methods with $3 \mathrm{~g}$ of sterilised particular material using glutamate (open triangles) or sucrose (open squares) (2\% w/v) as carbon sources. In case of buffered samples

(closed symbols), the medium was prepared in $100 \mathrm{mmol} \cdot \mathrm{l}^{-1}$ Tris/HCl buffer, $\mathrm{pH} 8.0$. absorbing at $280 \mathrm{~nm}$ (Fig. 3) not precipitable by boiling. The release of pigmented material was not detectable under the experimental conditions. Microscopic observation of sawdust particles after nine-day-treatment revealed that the particles remained intact and had a fibrillar character.

As the ability to solubilise solid materials does not seem to be restricted to lignite, also microorganisms other than fungi were tested for their lignite solubilisation activity. Therefore, an attempt was made to solubilise coal with microflora present in lignite. In the experiment shown in Fig. 4, nonsterilised lignite powder was used as the substrate. It was found that the microflora on non-sterilised lignite solubilised lignite to a higher extent than Trichoderma isolates. It should be noted that airborne microorganisms were present in the culture in addition to those present in lignite. Bacteria were predominant in the culture after 25 days of solubilisation, which caused increased turbidity of the suspension confirmed by microscopic observations (not shown). The bacterial species were not identified. Hence, it is possible that non-sterile lignite is easier to solubilise microbially than the autoclaved one (Fakoussa personal communication, see also Fakoussa and Hofrichter, 1999). Thus, the potential of bacteria in lignite solubilisation should be explored in the future. 

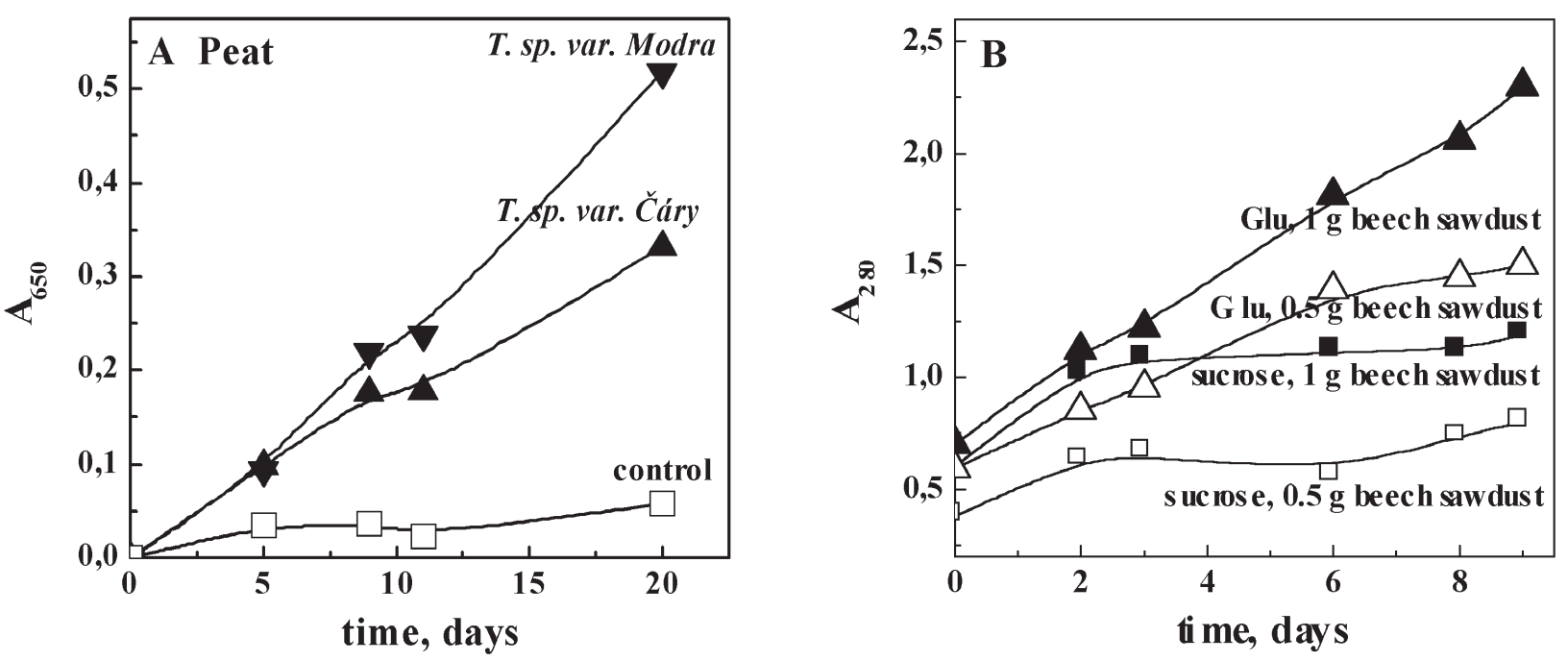

Fig. 3. Solubilisation of peat and wood sawdust by Trichoderma species.

A: Experiments were performed with sterilised peat $(1.5 \mathrm{~g})$ inoculated with Trichoderma sp. var. Čary

(closed upward triangles) or with Trichoderma sp. var. Modra (closed downward triangles).

Non-inoculated sterilised peat was analysed in parallel as control (squares). Glutamate ( $2 \% \mathrm{w} / \mathrm{v})$

was used as the carbon source.

B: Media with indicated carbon sources and mass of sterilised beech sawdust were treated as described in Materials and Methods. Samples withdrawn at indicated time were centrifuged $(20 \mathrm{~min}, 14000 \times \mathrm{g})$ and $\mathrm{A}_{280}$ was measured in aliquots against the medium without sawdust and inoculum. $\mathrm{A}_{280}$ of non-diluted samples are shown.

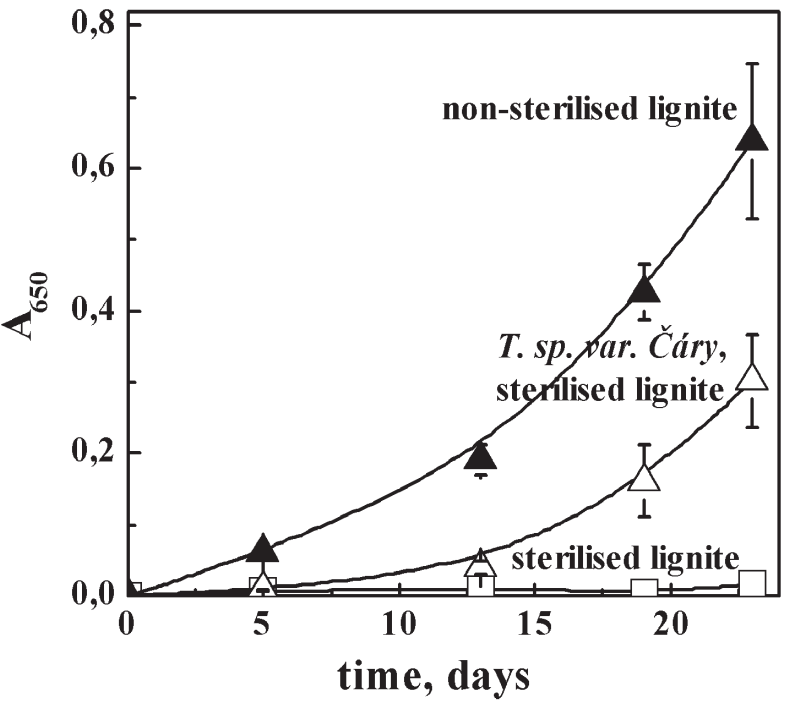

Fig. 4. Comparison of solubilisation activity of added Trichoderma sp. var. Čáry and indigenous microorganisms present in non-sterilised lignite. Media were inoculated with identical number of conidia using sterilised (open triangles) or non-sterilised (closed triangles) coal samples (kept in closed sterile containers) and solubilisation was carried out in duplicate assays as described in Materials and Methods with $1.5 \mathrm{~g}$ of particular material. Control (open squares) with sterilised lignite and without inoculation was proceeded in parallel.

\section{Growth of Trichoderma in lignite solubilisation experiments}

Solubilisation process initiated by inoculation with conidia starts after a delay of $1-7$ days in different experiments. The life cycle of filamentous fungi shows that germination of conidia and the beginning of the vegetative growth occur during the solubilisation lag phase. The presence of mycelia was observed in the first days of cultivation together with conidia and mostly conidia were present in the final phase of the experiment (not shown). The mass of protein extracted from the culture increased gradually and remained constant until the end of the experiment. When the medium was inoculated with vegetative mycelium, its mass increased in a similar time interval (Fig. 5). When non-sterilised lignite was used as the inoculum, the protein mass in the culture increased at a lower rate in an almost linear time course over a period of 27 days. This can be explained by the growth of several populations of micro-organisms with different multiplication times.

\section{Enzyme activities of Trichoderma species during lignite and peat solubilisation}

Lignite solubilisation medium in the presence or absence of fungus did not display any enzymatic activity mentioned in Materials and Methods except for minute laccase activity when particulate material was taken as the enzyme source (Table 1). 


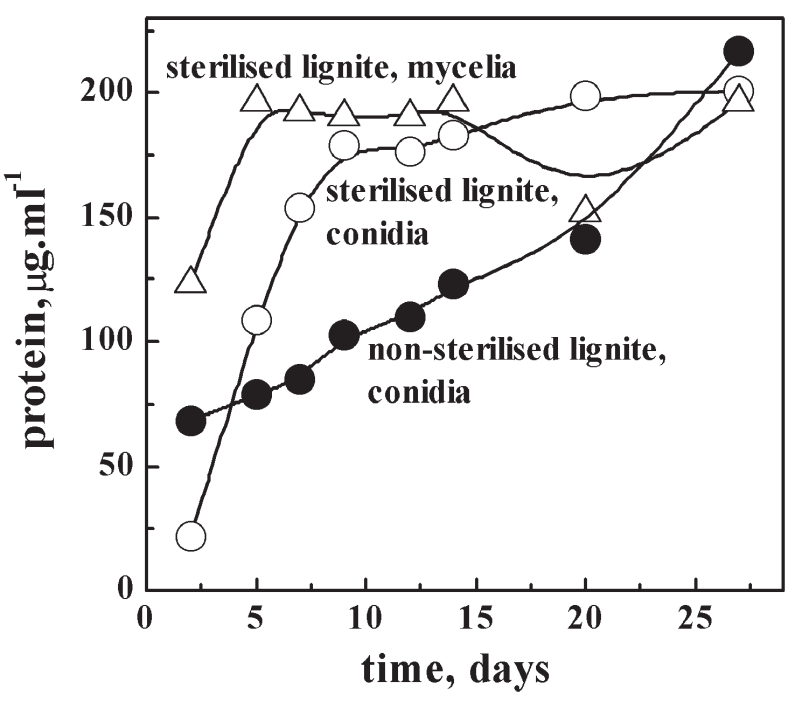

Fig. 5. Changes in protein content in the culture of Trichoderma sp. var. Čáry during the solubilisation experiment after inoculation with mycelia or conidia.

Sterilised lignite $(1.5 \mathrm{~g})$ was inoculated with conidia (open circles) or $24 \mathrm{~h}$ old mycelia corresponding to $80 \mu \mathrm{g} / \mathrm{ml}$ of protein (open triangles). In parallel, non-sterilised lignite was inoculated with conidia as the control (closed circles). At indicated time, aliquots of medium were withdrawn, and the protein content was determined after alkaline extraction of proteins as described in Materials and Methods.
However, peat solubilisation revealed the presence of several enzymes with activities dependent on the age of the culture. Besides the activity of laccase, also that of a veratryl-alocohol oxidising, lignin-peroxidase-like enzyme was found as well as activities of cellulase, xylanase, laminarinase, amylase, lichenase, and proteinase which were detected using chromolytic substrates. These results are not shown as the chromolytic substrates required long-term incubation and are regarded as preliminary. Cellulase and laminarinase activities were measured by the DNS method at various stages of the experiment (Table 1). Activities of these enzymes were differently localised. Whereas the lignin-peroxidase-like activity was present in the supernatant after spinning down the particulate material (i.e., coal particles and microbes), laccase activity was connected to microbial cells (conidia) (Table 1).

\section{Characterisation of solubilisation products}

Solubilisate obtained from lignite or peat after spinning down the particulate material $(20 \mathrm{~min}$, $12000 \times \mathrm{g}$ ) was the true solution which could be filtered through a $0.22 \mu \mathrm{m}$ nitrocellulose membrane filter without retaining $\mathrm{A}_{650}$. However, the material absorbing at $\mathrm{A}_{650}$ was not dialysable through the dialysation membrane with the cut-off of about $5 \mathrm{kDa}$ (not shown). This indicates that the solubilisate is water-soluble polymer. UV spectra of the solubilisate showed a broad shoulder at 250-

Tab. 1. Enzyme activities in lignite solubilisate by Trichoderma sp. var. Čáry. Results are typical of three similar experiments. Note that laccase was measured in the suspension whereas other enzymes were measured in the medium devoid of particulate material.

\begin{tabular}{|c|c|c|c|c|c|}
\hline $\begin{array}{l}\text { Carbon } \\
\text { source }\end{array}$ & Enzyme & $\begin{array}{l}\text { Day of } 1^{\text {st }} \text { measure- } \\
\text { ment } / \text { activity }{ }^{1}\end{array}$ & $\begin{array}{l}\text { Day of } 2^{\text {nd }} \text { measure- } \\
\text { ment } / \text { activity }{ }^{1}\end{array}$ & $\begin{array}{l}\text { Day of } 3^{\text {rd }} \text { measure- } \\
\text { ment } / \text { activity }{ }^{1}\end{array}$ & $\begin{array}{l}\text { Trichoderma } \\
\text { strain }\end{array}$ \\
\hline Lignite & Laccase & $9 / 0.5$ pkat. $\mathrm{mg}_{\mathrm{p}}^{-1}$ & $20 / 3.2$ pkat.mg ${ }_{\mathrm{p}}^{-1}$ & $23 / 4.0$ pkat.mg ${ }_{\mathrm{p}}^{-1}$ & T. sp. var. Čáry \\
\hline Lignite & Laccase & $9 / 2.3$ pkat. $\mathrm{mg}_{\mathrm{p}}^{-1}$ & $20 / 4.2$ pkat.mg ${ }_{\mathrm{p}}^{-1}$ & $23 / 5.3$ pkat. $\mathrm{mg}_{\mathrm{p}}^{-1}$ & T. sp. var. Modra \\
\hline Peat & Laccase & $9 / 8.8$ pkat. $\mathrm{mg}_{\mathrm{p}}^{-1}$ & $20 / 7.1$ pkat.mg ${ }_{\mathrm{p}}^{-1}$ & $23 / 8.0$ pkat.mg ${ }_{\mathrm{p}}^{-1}$ & T. sp. var. Čáry \\
\hline Peat & Laccase & $9 / 10.9$ pkat.mg ${ }_{p}^{-1}$ & $20 / 12.8$ pkat.mg ${ }_{\mathrm{p}}^{-1}$ & $23 / 15.0$ pkat.mg ${ }_{p}^{-1}$ & T. sp. var. Modra \\
\hline Peat & $\begin{array}{l}\text { Lignin- } \\
\text { peroxidase- } \\
\text { like activity }\end{array}$ & $7 / 4.8$ nkat.ml ${ }^{-1}$ & $11 / 3.1$ nkat.ml ${ }^{-1}$ & $20 / 0$ nkat.ml $l^{-1}$ & T. sp. var. Čáry \\
\hline Peat & $\begin{array}{l}\text { Lignin- } \\
\text { peroxidase- } \\
\text { like activity }\end{array}$ & 7 / 2.4 nkat.ml $l^{-1}$ & $11 / 5.6$ nkat.ml $l^{-1}$ & $20 / 0$ nkat.ml ${ }^{-1}$ & T. sp. var. Modra \\
\hline Peat & Cellulase & $6 / 23$ nkat.ml $l^{-1}$ & $12 / 43$ nkat.ml $l^{-1}$ & $21 / 0$ nkat.ml $l^{-1}$ & T. sp. var. Čáry \\
\hline Peat & Cellulase & $6 / 17$ nkat.ml $l^{-1}$ & $12 / 28.5$ nkat.ml $l^{-1}$ & $21 / 11$ nkat.ml $l^{-1}$ & T. sp. var. Modra \\
\hline Peat & Laminarinase & $6 / 2.4$ nkat. $\mathrm{ml}^{-1}$ & $12 / 4.6$ nkat.ml ${ }^{-1}$ & $21 / 0$ nkat.ml $l^{-1}$ & T. sp. var. Čáry \\
\hline Peat & Laminarinase & $6 / 8.2$ nkat.ml $l^{-1}$ & $12 / 5.8$ nkat.ml ${ }^{-1}$ & 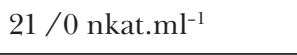 & T. sp. var. Modra \\
\hline
\end{tabular}

${ }^{1} \mathrm{mg} \mathrm{p}_{\mathrm{p}} \mathrm{mg}$ of proteins 


\section{Dialysed sample of solubilisate}

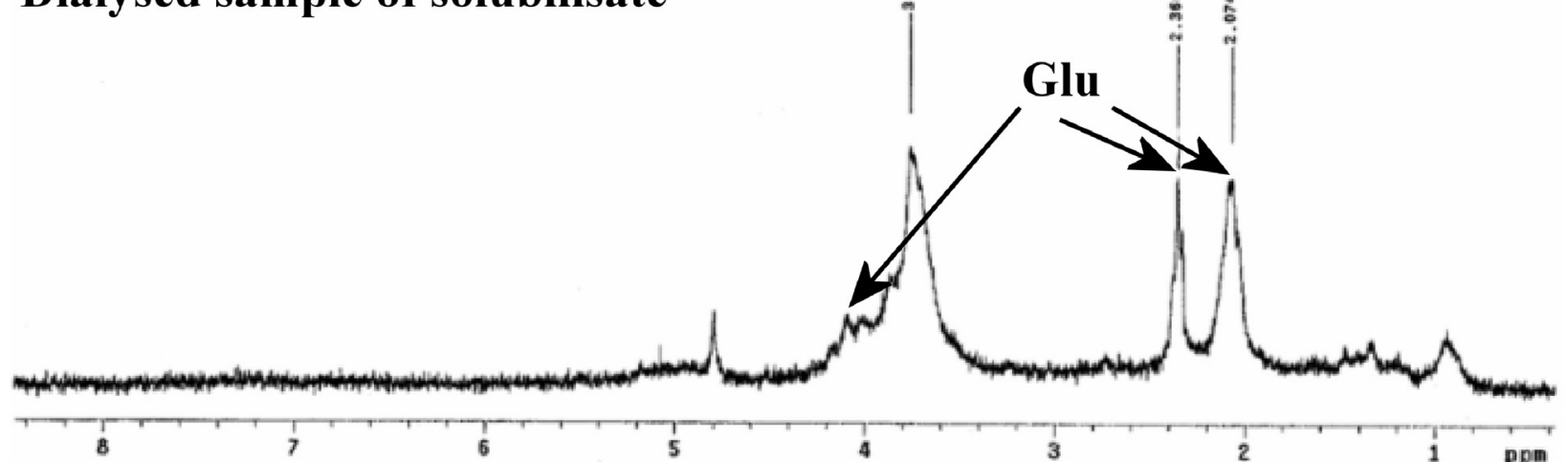

\section{Dialysate of solubilisate}

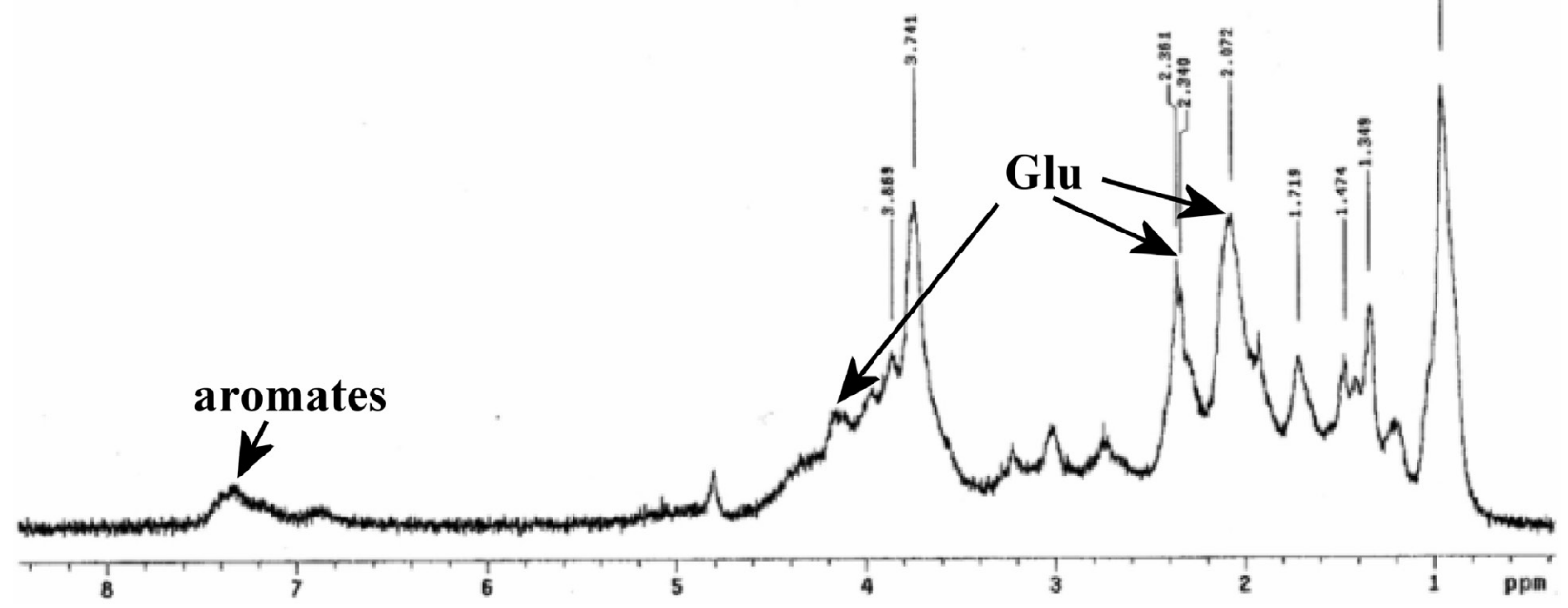

Fig. 6. ${ }^{1} \mathrm{H}-\mathrm{NMR}$ spectra of both non-dialysable and dialysable fractions of solubilisate.

Solubilisate from $100 \mathrm{ml}$ of medium (produced by Trichoderma sp. var. Čáry) was centrifuged $10 \mathrm{~min}$ at $14000 \times \mathrm{g}$ and dialysed against $1 \mathrm{l}$ of water for three days. Both dialysed sample (upper panel) and dialysate (lower panel) were lyophilised. Lyophilisates were dissolved in deuterated water and ${ }^{1} \mathrm{H}-\mathrm{NMR}$ spectra were measured as described in Materials and Methods.

$290 \mathrm{~nm}$ which was absent in the coal suspension cultivated under identical cultivation conditions without inoculation with fungus (Trichoderma sp., var. Čáry) for 30 days (not shown). Dialysed and lyophilised solubilisate was analysed by ${ }^{1} \mathrm{H}-\mathrm{NMR}$ (Fig. 6, upper panel). Phenolic moieties typical for lignin are hardly visible in this spectrum (about $7.35 \mathrm{ppm}$ ) probably due to the polymeric state of the molecule. In parallel, ${ }^{1} \mathrm{H}-\mathrm{NMR}$ spectrum of lyophilised dialysate (i.e. dialysable part of the solubilisate) showed the presence of phenolic compounds (6.9 and $7.35 \mathrm{ppm}$ ) as well as of glutamate; however, the complexity of spectra and broadening of bands did not enable identification of other compounds. At present, dialysable solubilisate is fractionated into groups according to charge and polarity with the aim to simplify the mixture enabling thus its ${ }^{1} \mathrm{H}-\mathrm{NMR}$ or GC/MS analysis.

\section{Lignite solubilisation product as carbon source for bacteria}

A paper by Hölker et al. (1999) and the above experiments (Figs. 1 and 6) indicate that fungi are able to convert a part of the solubilisate to less complex compounds. Other experiments indicate (Figs. 4 and 5) that bacteria are equally capable of lignite solubilisation. Further degradation of the solubilisate by bacteria was tested. For these experiments, bacterial strains isolated from lignite were chosen similarly as fungi (see Materials and Methods). Individual isolates (Ba4, Ba5, Ba8A, Ba8B, Ba9A, Ba9B) were identified as gram-negative bacilli (not shown) and their molecular typisation will be done later. Sterilised solubilisate was inoculated with liquid exponential culture of bacteria grown on the MP medium. The culture growth was monitored by measuring $\mathrm{A}_{600}$ against the sterilised solubilisate 
(not shown), or by the increase of protein content in the solubilisate (Table 2). After removing bacteria and lignite, the medium was dialysed, lyophilised and analysed as above. In culture Ba5, the lyophilisate did not dissolve completely in water and the presence of polymeric material not soluble either in organic solvents or in detergents was identified. Solubilisates from other cultures were completely soluble in water; however, their ${ }^{1} \mathrm{H}-\mathrm{NMR}$ spectra were very similar to those shown in Fig. 6 (not shown).

Tab. 2. Increase in biomass measured as protein content during the cultivation of ligniteborne bacteria with lignite solubilisate obtained from the isolate Trichoderma $s p$. var. Ćáry. The solubilisate was dialysed, lyophilised, and dissolved with water to the original volume. After sterilisation, the medium was inoculated with suspensions of bacterial isolates and submerged to be cultivated for 13 days. Protein content was measured immediately after the inoculation and after the end of the cultivation by the Bradford method.

\begin{tabular}{|c|c|c|}
\hline \multirow[t]{2}{*}{ Isolate } & \multicolumn{2}{|c|}{ Protein content in the medium, $\propto \mathrm{g} \cdot \mathrm{ml}^{-1}$} \\
\hline & Day 0 (inoculum) & Day 13 (end of cultivation) \\
\hline $\mathrm{Ba} 4$ & 3.76 & 16.12 \\
\hline Ba5 & 3.42 & 15.25 \\
\hline $\mathrm{Ba} 8 \mathrm{~A}$ & 3.01 & 16.42 \\
\hline Ba8B & 3.01 & 14.65 \\
\hline Ba9A & 3.11 & 17.81 \\
\hline Ba9B & 3.11 & 18.61 \\
\hline
\end{tabular}

\section{Discussion}

Since the search for coal degrading microorganisms has started, a number of fungal species from the surface of coal pieces (Kitamura et al., 1993), rotten wood and litter (Hofrichter and Fritsche, 1996) or in 0.5-20 years-old forest fire regions (Bublitz et al., 1994) have been screened.

Fungi used in this paper were isolated from the underground of a lignite mine from the depth of about 170 meters. In fact, Trichoderma species are rather rare fungal species, but a number of fungal and bacterial strains were isolated which remain to be characterised. These micro-organisms were tested for their ability to attack the surrounding macromolecular matrix and the results show that Trichoderma species derived from underground coal are capable to attack coal similarly to that of Trichoderma strains isolated from the Earth surface (Hölker et al., 1999).
Solubilisation of lignite observed above is a complex process. First, it requires an alkaline medium created by the transport and metabolism of carboxylic and/or amino acids (Hölker et al., 1995, 1999; Figs. 1 and 2). This process, however, does not seem to be the final stage of the fungal action on lignite as also dialysable compounds are present in the solubilisate (Fig. 6) and enzyme activities other than hydrolases were induced during the solubilisation process (Table 1).

The experiment shown in Fig. 5 indicates that both conidia and vegetative mycelia are effective in the solubilisation process. When conidia were used as inoculum, they developed to mycelia which, after about 5-7 days, differentiated into the next generation-conidia. The time course of appearance of oxidative enzymes (Conesa et al., 2002) participating in coal solubilisation (Hölker et al., 2002a, 2002b; Laborda et al., 1999; Ralph and Catcheside, 1999; Table 1) indicates that these enzymes appear in the phase of cultivation where no mycelia were observed, thus suggesting their activity during the conidia formation and/or maturation. It is remarkable that these enzymes appear only temporarily in the medium (Table 1). If they were induced by lignite-derived compounds, a different time course of induction would be expected. Therefore, it seems more probable that their activity is primarily involved in processes proceeding simultaneously with the degradation of lignin, e.g. maturation of conidia, although they could be involved in the degradation of the complex substrate. These results also indicate that conidia present in the (submerged) culture are not dormant structures but that they are metabolically active. This is supported by the fact that also less complex substrates, such as peat or wood (Fig. 3), are degraded using the above solubilisation method which is accompanied by the appearance of both oxidoreductases and hydrolases (Table 1).

Although our work has been focused on the solubilisation of coal by fungi, some experiments indicated that bacteria are equally if not more effective in attacking coal (Fig. 4) and the increase of biomass indicates that bacteria can use the solubilisate as a carbon source (Table 2). Metabolic products of both bacterial and fungal attack on coal remain to be identified.

In summary, solubilisation of coal is feasible and can be used for the transformation of at least a part of solid coal to soluble compounds and/or biomasss.

\section{Acknowledgement \\ This work was supported by the project Creating the Com- petence Center for Research and Development in the Field of Molecular Medicine (ITMS 26240220071).}




\section{References}

Ausubel F, Brent R, Kingston RE, Moore DD, Seidman JG, Smith JA, Struhl K (1992) Short protocols in molecular biology. Wiley \& Sons, New York.

Bublitz F, Günther T, Fritsche W (1994) Fuel Proceeding Technology 40, 347-354.

Cohen MS, Bowers WC, Aronson H, Gray ET Jr. (1987) Applied and Environmental Microbiology 53: 2840-2843.

Conesa A, Punt PJ, van den Hondel CA (2002) Journal of Biotechnology 93: 143-158.

Etemadzadeh SS, Emtiazi G, Etemadifar Z (2016) Current Microbiology 72: 707-715. doi: 10.1007/s00284-0161008-x.

Fakoussa RM (1981) PhD Thesis (in German), University of Bonn, Germany.

Fakoussa RM, Hofrichter M (1999) Applied Microbiology and Biotechnology 52: 25-40.

Fritsche W, Hofrichter M, Ziegenhagen D (1999) In: Steinbüchel A. (Ed.), Biochemical Principles and Mechanisms of Biosynthesis and Biodegradation of Polymers (pp 265-272). Wiley-VCH Verlag GmbH, Weinheim.

Hofrichter M, Fritsche W (1996) Applied Microbiology and Biotechnology 47: 419-424.

Hofrichter M, Ziegenhagen D, Sorge S, Ullrich R, Bublitz F, Fritsche W (1999) Applied Microbiology and Biotechnology 52: 78-84.

Hölker U, Fakoussa RM, Höfer M (1995) Applied Microbiology and Biotechnology 44: 351-355.

Hölker U, Ludwig S, Scheel T, Höfer M (1999) Applied Microbiology and Biotechnology 52: 57-59.

Hölker U, Dohse J, Höfer M (2002a) Folia Microbiologica 47: 423-427.

Hölker U, Schmiers H, Grosse S, Winkelhöfer M, Polsakiewicz M, Ludwig S, Dohse J, Höfer M (2002b) Journal of Industrial Microbiology and Biotechnology 28: 207-212.
Kitamura K, Ohmura N, Saiki H (1993) Applied Biochemistry and Biotechnology 38: 1-13.

Klein J, Fakoussa RM, Hölker U, Hofrichter M, Schmiers H, Sinder C, Steinbüchel A (2001) In: Rehm, H. J. (Ed.) Biotechnology, Vol 10 (pp 153-189), Wiley-VCH Verlag GmbH, Weinheim.

Kliăn OI, Kulikova NA, Konstantinov AI, Fedorova TV, Landesman EO, Koroleva OV (2013) Priklady Biokhimii i Mikrobiologii 49: 292-300.

Kuwahara M, Glenn JK, Morgan MA, Gold MH (1984) FEBS Letters 169: 247-250.

Laborda F, Monistrol IF, Luna N, Fernandez M (1999) Applied Microbiology and Biotechnology 52: 49-56.

Liu Y, Zhu J, Gao W, Guo Z, Xue C, Pang J, Shu L (2019) Environmental Sciences Pollution Research International 26: 34368-34376. doi: 10.1007/s11356019-06567-z.

Mukasa-Mugerwa TT, Dames JF, Rose PD (2011) Biodegradation 22: 129-141. doi: 10.1007/s10532-0109382-8.

Sekhohola LM, Igbinigie EE, Cowan AK (2013) Biodegradation 24: 305-318

Ralph JP, Catcheside DE (1999) Applied Microbiology and Biotechnology 52: 70-77.

Scheel T, Mönkemann H, Hölker U, Ludwig S, Höfer M (1997) In: Ziegler A, van Heek KH, Klein J, Wanzel W (Eds.), Proceedings of ICCS (pp 1677-1679). P\&W Druck und Verlag, Essen.

Scheel T, Hölker U, Ludwig S, Höfer M (1999) Applied Microbiology and Biotechnology 52: 66-69.

Scheel T, Höfer M, Ludwig S, Hölker U (2000) Applied Microbiology and Biotechnology 54: 686-691.

White TJ, Bruns T, Lee S, Taylor J (1990) In: Innis MA, Gelfand DH, Sninsky JJ, White TJ (Eds.), PCR Protocols: A guide to methods and applications (pp 315-322), Academic Press, New York.

Yuan HL, Yang JS, Wang FQ, Chen WX (2006) Priklady Biokhimii i Mikrobiologii 42: 59-62. 